\title{
Makna Kehilangan Orangtua Bagi Remaja di Panti Sosial Bina Remaja Indralaya Sumatera Selatan; Studi Fenomenologi
}

\author{
$\mathrm{S} \mathrm{u} \mathrm{z} \mathrm{a} \mathrm{n} \mathrm{n} \mathrm{a}$ \\ Dosen Keperawatan Jiwa PSIK STIKes Muhammadiyah Palembang \\ Email: suzanna.stikesmp@gmail.com
}

\section{ARTICLE INFO}

Article history:

Received 3 March 2018

Revised 14 May 2018

Accepted 15 May 2018

Keyword:

Losing

Parents

Adolescents

DOI:http://dx.doi.org/10.30604/jika.v3i1.86

\begin{abstract}
A B S T R A C T
Losing is a condition who has ever been in individual a long life. The objective of the research was to find the meaning of parents losing for adolescent of social home at Bina Remaja. It was important in adolescents respon to have parents losing process and also adaption in Life Phase Qrowth. The Qualitative research used Phenomenology Study with Indepth Interveiw and Field Notes by involved six informans. The result of the study found there were five themes losing parents such as: The deep sadness in different scale, losing parents figure, lack of affections, there is no one to share, and the unbreakable family condition. The losing Phases were denial, anger, and acceptance. In conclusion the deep sadness in adolescentt was found hey can accept it. Hoping and Praying of adolescent is kind of their love to them.
\end{abstract}

\section{PENDAHULUAN}

Kehidupan manusia pada hakikatnya mengalami pertumbuhan dan perkembangan. Rentang kehidupan manusia manusia melewati tahap-tahap perkembangan dimana setiap tahap memiliki tugas-tugas perkembangan yang harus dikuasai dan diselesaikan. Sebagian besar dari kita ingin berusaha menguasai dan menyelesaikannya pada waktu yang tepat . Beberapa orang dapat berhasil, sedangkan yang lain kemungkinan tidak berhasil atau terlalu cepat dari tahap yang seharusnya. Tahapan pertumbuhan dan perkembangan manusia dimulai dari masa sebelum lahir,kelahiran, masa bayi, masa anak-anak, masa remaja, masa dewasa dan usia lanjut (Hurlock, 2007).

Menurut Havighurst (dalam Monks, Knoers \& Haditono, 2001) Masa dewasa adalah masa yang sangat panjang (20-40 tahun), dimana sumber potensi dan kemampuan bertumpu pada usia ini. Masa ini adalah peralihan dari masa remaja yang masih dalam ketergantungan menuju masa dewasa, yang menuntut kemandirian dan diujung fase ini adalah fase dewasa akhir, dimana kemampuan sedikit demi sedikit akan berkurang. Sehingga masa dewasa awal adalah masa yang paling penting 
dalam hidup seseorang dalam masa penitian karir/pekerjaan/sumber penghasilan yang tetap. Masa ini juga adalah masa dimana kematangan emosi memegang peranan penting. Seseorang yang ada pada masa ini, harus bisa menempatkan dirinya pada situasi yang berbeda; problem rumah tangga, masalah pekerjaan, pengasuhan anak, hidup berkeluarga, menjadi warga masyarakat, pemimpin, suami/istri membutuhkan kestabilan emosi yang baik.

Usia lanjut (later maturity) merupakan masa dimana mereka berada pada usia lima puluh tahun lebih dan mulai menyesuaikan diri dengan penurunan kekuatan fisik dan kesehatan, menyesuaikan diri dengan situasi pensiun dan penghasilan yang semakin berkurang, menyesuaikan diri dengan keadaan kehilangan pasangan, membangun hubungan baik dengan sesama usia lanjut dan pada akhirnya kesiapan menghadapi kematian.

Kematian dan kehilangan merupakan bagian yang tidak terlepas dari kehidupan manusia. Kematian merupakan fakta hidup, setiap manusia di dunia ini pasti akan mati. Kematian tidak hanya dialami oleh kaum usia lanjut, tapi juga oleh orang-orang yang masih muda, anak-anak bahkan bayi. Seseorang dapat meningal karena sakit, usia lanjut, kecelakaan, dan sebagainya. Hal ini sejalan dengan firman Allah dalam AlQur'an "Dimana saja kamu berada, kematian akan mendapatkan kamu, kendatipun kamu di dalam benteng yang tinggi dan kokoh" (An-nisa: 4:78). Jika seseorang meninggal dunia, peristiwa kematian tersebut tidak hanya melibatkan dirinya sendiri namun juga melibatkan orang lain, yaitu orang-orang yang ditinggalkannya, kematian dapat menimbulkan penderitaan bagi orang-orang yang mencintai orang yang meninggal tersebut (Turner \& Helms, 1995 dalam Hurlock, 2007).

Kehilangan adalah suatu keadaan individu mengalami kehilangan sesuatu yang sebelumnya ada dan dimiliki. Kehilangan merupakan sesuatu yang sulit dihindari (Stuart, 2005), seperti kehilangan harta, kesehatan, orang yang dicintai, dan kesempatan. Kehilangan juga mempengaruhi proses psikologis atau kejiwaan, hal ini dikarenakan kehilangan memiliki tahapan proses kehilangan yaitu penyangkalan, marah, penawaran, depresi, dan penerimaan. Setiap individu akan melalui setiap tahapan tersebut, tetapi cepat atau lamanya sesorang melalui bergantung pada koping individu dan sistem dukungan sosial yang tersedia, bahkan ada stagnasi pada satu fase marah atau depresi. Jika individu tetap berada di satu tahap dalam waktu yang sangat lama bahkan bertahuntahun dan tidak mencapai tahap penerimaan, disitulah awal terjadinya gangguan jiwa. Suatu saat apabila terjadi kehilangan kembali, maka akan sulit bagi individu untuk mencapai tahap penerimaan dan kemungkinan akan menjadi sebuah proses yang disfungsional (Yusuf, 2015).

Peristiwa kematian diawali dengan bereavement, yaitu suatu kehilangan karena kematian seseorang yang dirasakan dekat dengan yang sedang berduka dan proses penyesuaian diri kepada kehilangan (Papalia, 2008). Seseorang yang mengalami bereavement wajar apabila ia mengalami grief. Menurut Papalia (2008) grief adalah respon emosional yang dialami pada fase awal berduka. Menurut Yuliawati dalam (Adina, 2013) sebagian besar remaja yang mengalami ketiadaan ayah pada usia 11 tahun sampai dengan 15 tahun (usia remaja) justru mengalami masalah emosi (merasa kesepian, merasa kesedihan, serta merasa kurang diperhatikan). Peristiwa kematian bagi remaja akan lebih buruk lagi jika peristiwa kematian secara tiba-tiba atau mendadak dan tak terpikirkan oleh mereka. Peristiwa kematian mendadak atau tidak diharapkan akan benar-benar mengejutkan bagi orang yang ditinggalkan, karena mereka tidak memiliki kesempatan untuk menyiapkan diri secara psikologis untuk menghadapi kehilangan karena kematian orang yang dekat dengan dirinya. 
Berdasarkan penelitian yang dilakukan oleh Suprihatin (2013) bahwa grief yang muncul dapat dilihat dalam proses perkembangan grief yang dilalui oleh subjek yaitu pada tahap inisial respon reaksi yang muncul adalah shock, kehilangan, kecemasan, dan kekhawatiran. Pada tahap intermediate reaksi yang muncul adalah kemarahan, kesepian dan kerinduan, sedangkan pada tahap recovery reaksi yang muncul adalah kehidupan subjek sudah kembali normal.

Para remaja berduka proses berduka yang terjadi lebih sama dengan orang dewasa, namun karena pada tingkat pertumbuhan ini para remaja sering merasakan emosi cenderung fluktuatif sebagai akibat dari stresnya. Remaja bisa merasakan dampak yang sangat besar akibat kesedihan yang mereka rasakan setelah putus hubungan, perpisahan orangtua atau kematian seseorang yang dekat dengan mereka. Mereka bisa menutup diri, tertekan dan mudah marah.

Dalam hal ini diperlukan hubungan yang baik dengan sesama anggota keluarga yang lain untuk membantu menyelesaikan masalah sehingga tidak terjadi kondisi depresi pada remaja. Sarwono (2016).

Berdasarkan penelitian Nurhidayati (2014) yang menjelaskan pengalaman dari kematian orang tua melalui wawancara makna kematian orang tua adalah kehilangan. Adapun temanya adalah kehilangan yang dirasakan oleh remaja meliputi kehilangan perhatian dan kasih sayang, kehilangan figur yang dapat dijadikan sebagai panutan, kehilangan perlindungan, serta kehilangan teman berbagi, kehilangan keutuhan keluarga serta kehilangan arah.

Hal yang senada dalam penelitian Suprihatin (2013) yang menguraikan bahwa Grief atau proses berduka dilalui oleh informan yaitu pada tahap inisial respon reaksi yang muncul adalah shock, kehilangan, kecemasan, dan kekhawatiran. Pada tahap intermediate reaksi yang muncul adalah kemarahan, kesepian dan kerinduan, sedangkan pada tahap recovery reaksi yang muncul adalah kehidupan subjek sudah kembali normal. Adapun faktor yang menyebabkan grief yang dialami yaitu hubungan subjek dengan almarhum, kepribadian, usia, jenis kelamin orang yang ditinggalkan, proses kematian, dukungan dari orang-orang terdekat dan posisi subjek dalam keluarga. Faktor penyebab yaitu kelekatan semakin subjek memiliki ikatan yang kuat dengan almarhum, waktu yang dibutuhkan untuk melalui grief akan semakin lama.

Penelitian Cahyasari (2008) menjelaskan bahwa Grief dengan reaksi berduka yang muncul yaitu: ekspresi fisik, kognittif, afektif dan tingkah laku yang dirasakan oleh informan. Dengan adanya penolakan, tangisan kekecewaan, kemarahan, rasa kehilangan, tidak mau untuk berinteraksi social lalu pada fase akhir mulai bisa menerima keadaan. Adapun faktor yang menyebabkan grief yang dialami subjek yaitu hubungan individu dengan almarhum, proses kematian, jenis kelamin orang yang ditnggalkan, latar belakang keluarga, support system.

bahwa makna kematian orang tua bagi remaja adalah kehilangan. Adapun kehilangan yang dirasakan oleh remaja meliputi kehilangan sosok pemberi perhatian dan kasih sayang, kehilangan model, kehilangan sumber rasa aman, dan kehilangan teman berbagi. Remaja mengungkapkan perasaan kehilangannya dengan menangis, merasa sedih, melakukan penolakan, dan menyesal. gur pengganti yang dapat berfungsi mengisi

Penelitian dilakukan oleh Felicia (2016) ini difokuskan pada bagaimana remaja mengatasi sosial dengan berduka. Usia dan jenis kelamin tidak membuat perbedaan yang signifikan dalam pilihan remaja dari strategi coping. Hasil penelitian menunjukkan bahwa para remaja mengadopsi strategi untuk mengatasi kehilangan orang tua secara sosial. 
Sebagian remaja menghabiskan banyak waktu interaktif di sekolah, kelompok drama, klub sepak bola, tim bola basket dan dukungan kelompok penyuluhan sehingga rasa berduka dapat teralihkan.

Remaja berada dalam masa peralihan dari kanak-kanak kemasa dewasa Menurut Marmi (2015) Dalam masa peralihan itu pula remaja sedang mencari identitasnya. Dalam proses perkembangan yang serba sulit dan masa-masa membingungkan dirinya, remaja membutuhkan pengertian dan bantuan dari orang yang dicintai dan dekat dengannya terutama orang tuanya. Sebab dalam masa yang kritis seseorang kehilangan pegangan yang memadai dan pedoman hidupnya (Hurlock, dalam Adina 2013). Tetapi pada kenyataanya tidak semua remaja tinggal bersama orang tua, seperti halnya remaja yang tinggal di panti asuhan, mereka hanya mendapatkan lingkungan teman sebaya yang mereka anggap sebagai tempat berbagi dan pengasuh menggantikan peran orang tua hanya memberikan perhatian juga membimbing secara terbatas.

Pada remaja yang tidak memiliki orang tua tekanan-tekanan yang dialami akan semakin banyak terkait dengan tidak adanya orang tua sebagai sumber kasih sayang, perlindungan dan dukungan. Ketiadaan orang tua merupakan kondisi yang sangat kompleks bagi remaja. Margaret (Hurlock, 2007) melaporkan bahwa selain pemenuhan kebutuhan fisiologis, anak membutuhkan kasih sayang bagi perkembangan psikis yang sehat. Diketahui juga bahwa remaja dapat bertahan dengan baik dari situasi yang menekan bila remaja mempunyai hubungan yang dekat dan penuh kasih sayang dengan orang tua terutama ibu. Dalam kondisi yatim atau yatim piatu, hubungan yang penuh kasih sayang dengan orang tua tidak lagi dirasakan oleh remaja, dengan kondisi ini mereka harus tinggal di tempat selain rumah seperti yayasan atau panti asuhan karena tidak ada lagi orang yang merawatnya.

Kondisi panti asuhan dengan jumlah pengasuh yang tidak sebanding dengan remaja di panti asuhan dapat mejadi salah satu faktor resiko. Remaja dipanti asuhan menjadi kurang mendapat perhatian, kasih sayang atau bimbingan dari pengasuh secara mendalam. Dengan sedikit bimbingan, remaja harus mengatur hidup sendiri. Pengalaman di panti akan berpengaruh terhadap konsep diri dan kepribadian remaja yang tinggal disana. Selain jumlah pengasuh yang tidak sebanding, panti asuhan sering dianggap sebagai lembaga yang hanya menampung dan memenuhi kebutuhan fisik saja sehingga kebutuhan lain seperti kebutuhan emosional tidak terpenuhi dengan baik. Remaja dengan kehilangan orang tua diasumsikan memiliki masalah psikologis yang lebih banyak jika dibandingkan dengan remaja pada umumnya yang tinggal dirumah, masih memiliki orang tua utuh dan keluarga yang dipenuhi kehangatan.

Menurut Potter dan Perry (2005) kehilangan adalah suatu situasi actual maupun potensial yang dapat dialami individu ketika berpisah dengan sesuatu yang sebelumnya ada, baik sebagian atau keseluruhan atau perubahan dalam hidup. Bentuk kehilangan antara lain kehilangan obyek eksternal, kehilangan lingkungan yang familiar, kehilangan seseorang yang sangat berarti dan kehilangan kehidupan. Seorang individu yang mengalami kehilangan akan menunjukkan reaksi emosional yang berupa reaksi berduka. Reaksi emosional ini terjadi selama masa kehilangan dan dipengaruhi oleh kebudayaan atau kebiasaan individu yang dapat diwujudkan dalam berbagai cara yang unik pada masing-masing orang dipengaruhi pada pengalaman pribadi, ekspektasi budaya dan keyakinan spiritual yang dianutnya; reaksi emosional tersebut dialami anak jalanan yang kehilangan orang tua. Respon kehilangan pada remaja 
tentunya akan berbeda pada situasi remaja tinggal dalam satu rumah dengan yang tinggal tidak satu rumah seperti panti asuhan.

Data dari Kemensos (2013) didapatkan bahwa 8.000 panti asuhan yang mengelola 1,5 juta anak. Data Badan Pusat Statistik Sumsel (2014) terdapat 139 panti asuhan yang terdiri 133 swasta dan 6 pemerintah dengan 4504 jumlah anak asuh serta didapatkan alasan masuk bahwa kondisi orang tua baik ibu atau ayah yang telah meninggal dunia. Panti asuhan merupakan lembaga untuk membentuk perkembangan, keterampilan serta kasih sayang bagi anak yang tidak memiliki keluarga serta tidak tinggal bersama keluarga. Salah satu panti asuhan yang terdapat di Sumsel yaitu Panti Sosial Bina Remaja yang menerima anak asuhan dengan latar belakang putus sekolah, kehilangan orang tua dan anggota keluarga.

Berdasarkan studi pendahuluan yang dilakukan peneliti di Panti Sosial Bina Remaja Sumatera Selatan dari 50 remaja yang tinggal di panti, terdapat 15 remaja dengan kehilangan orang tuanya akibat kematian. Kehilangan orang tua yang dialami remaja penghuni panti tersebut disebabkan kematian karena sakit parah, usia lanjut, kecelakaan, dan sebagainya. Adapun petikan wawancara "Dulu, saya memiliki sosok untuk mencurahkan isi hati saya ketika saya sedih maupun ketika saya bahagia. Tapi, setelah ibu tiada saya tidak bisa lagi bercerita kepada ibu. Terkadang saya merasa sangat sedih dan merasa kalau saya sendiri" (W.01.Hmd). "Saya sangat sedih kadang menangis ketika selesai sholat, sedih kalau teringat ayah dulu, sedih banget apalagi saya tidak bisa menemani waktu diakhir kamatiannya"(W.02. Nrml).

Dalam penelitian Nurhidayati (2014) menguraikan bahwa kehilangan orang yang dicintai diidentifikasi sebagai suatu kehilangan yang sangat mendalam. Rasa kehilangan bersifat individual, karena setiap individu tidak akan merasakan hal yang sama tentang kehilangan. Sebagian individu akan merasa kehilangan hal yang biasa dalam hidupnya dan dapat menerimanya dengan sabar. Individu yang tidak mampu menerima kehilangan orang yang disayang dalam hidupnya akan merasa sendiri dan berada dalam keterpurukan.

Berdasarkan penjelasan di atas dapat diketahui bahwa makna kehilangan orang tua bagi remaja berbeda dan dapat berlangsung lama bahkan bertahun-tahun. Kehilangan yang dialami remaja tidak boleh dibiarkan berlarut-larut karena dapat mengganggu kejiwaan remaja seperti stress bahkan depresi sehingga tidak dapat melakukan tugas perkembangannya, terutama perkembangan emosional dan sosial mereka sehingga sedikit memiliki andil dalam setiap perilaku mereka. Oleh karena itu, peneliti tertarik melakukan penelitian mengenai "Studi Fenomenologi Makna Kehilangan Orang Tua Bagi Remaja di Panti Sosial Bina Remaja Indralaya Sumatera Selatan.

\section{METODE}

Penelitian menggunakan rancangan penelitian kualitatif dengan pendekatan fenomenologi yaitu: penelitian yang menggunakan pendekatan naturalistik untuk mencari dan menemukan pengertian atau pemahaman tentang fenomena mengenai apa yang dialami oleh subjek penelitian dengan cara deskripsi dalam bentuk katakata dan bahasa dalam suatu latar yang berkonteks khusus dan alamiah (Maleong, 2010). Adapun jumlah informan yang telah mengalami saturasi data sebanyak 6 informan. Penelitian ini dilakukan pada 10 - 28 April 2017 di Panti Sosial Bina Remaja Sumatera Selatan Indralaya KM 33 Ogan Ilir.

Pengumpulan data dalam penelitian dilakukan dengan wawancara mendalam (indepth interview) dan catatan lapangan (field notes). Teknik wawancara mendalam 
digunakan untuk mengeksplorasi makna kehilangan dengan 10 pertanyaan sebagai panduan wawancara yang berdasarkan pada fase kehilangan menurut Kubler Rose. Setelah didapatkan jawaban dari informan dalam bentuk pernyataan lagi dilanjutkan dengan analisa data kualitatif.

Menurut Afiyati (2014) dengan tahapan analisa data kualitatif sebagai berikut: Memberi gambaran pengalaman personal terhadap fenomena yang diteliti, yaitu peneliti mulai dengan mendengarkan deskripsi verbal partisipan, membaca dan membaca ulang deskriptif tersebut. Membuat daftar pertanyaan yang signifikan. Peneliti menemukan pertanyanpertanyaan tentang bagaimana para partisipannya mengalami berbagai pengalaman mereka yang dibuat dalam suatu daftar pertanyaan-pertanyaan yang signifikan. Mengelompokkan pertanyaan yang signifikan tersebut dikumpul dalam suatu unit data/ informasi yang lebih besar, yang disebut "unit meaning" atau tematema. Menuliskan deskriptif atau interpretasi "apa" yang dialami para partisipan terkait fenomena yag diteliti. Ini yang disebut "suatu deskriptf tersrtuktural" tentang suatu pengalaman - apa yang dialami- dan dilengkapi contoh-contoh verbatim para partisipan. Menuliskan "bagaimana" pengalaman yang dialami pertisipan .ini yang disebut dengan " deskripsi structural", dan peneliti merekflesikan pada setting atau fenomena yag diteliti dialami partisipan. Menuliskan deskripsi gabungan (interpretasi data), yaitu menggabungkan deskripsi tekstural dan strukural. Ini yang disebut "intisari" (essence) dari pengalaman para partisipan dan merepresentasikan aspek inti dari studi fenoenologi yang dituliskan peneliti melalui data.

\section{HASIL DAN PEMBAHASAN}

Berdasarkan hasil wawancara mendalam dan catatan lapangan selama proses pengambilan data Penelitian ini menghasilkan lima tema yaitu: 1) Kesedihan yang mendalam dalam rentang berbeda, 2) hilangnya figur orang tua 3) Kasih sayang yang berkurang, 4) tiada lagi tempat Berbagi, 5) Kondisi keluarga yang tidak lagi utuh.

\section{Tema 1: Kesedihan yang mendalam dalam rentang berbeda}

Berdasarkan wawancara mendalam, didapatkan tema yang pertama yaitu Kesediahan yang mendalam dalam rentang yang berbeda adalah perasaan remaja terhadap kehilangan sosok ibu dan perasaan remaja terhadap kehilangan sosok bapak. Pada kategori pertama, terdapat 2 partisipan yang mengalami perasaan kesedihan terhadap kehilangan sosok ibu yaitu partisipan 1 dan partisipan 4. Kedua partisipan merasakan hal yang sama yaitu merasakan kesedihan kehiangan sosok ibu. Selain itu 4 dari 6 partisipan juga mengatakan perasaan remaja terhadap kehilangan sosok bapak bahwa partisipan merasakan kesedihan yang teramat menyakitkan dan perasaan itu sering menghampirinya. Berikut ungkapan partisipan:

"Sedih banget sekitar 3 bulanan, menangis dan berdiam diri di kamar... gimana kalau orang tua tinggal satu susah kalau masak saja itu susah, saya yang masak saya'’.(Pl)

"Iya, kalau kehilangan orang tua itu pastinya sedih ya,waktu itu kan masih sekolah pas mau perpisahan tiba-tiba orang tua dari kawan aku datang ngasih kabar bahwa ibu saya itu sudah meninggal, satu bulan lebih saya merasakannya”. (P4) "Iya sedih lah, nangis". (P4)

"Iya sedih, perasaan nya nggak mau kehilangan orang tua, “. (P4) ”ada dua tahun lamanya habis itu gak lagi sedih".(P4)

"Sering sedih, ketika sedang sendiri bahkan sekarang masih terkenang selama 4 bulan lamanya, makanya saya itu nggak 
mau sendiri, karna pasti aku teringat sama orang tua kandung saya”.(menundukan kepala”. (P2)

Menagis, ya sedih, marah terlalu marah, cumo ngrasa dak mau sekolah, nunggu dulu, menenangkan dulu 1 tahun”.(P3)

"Masih nangis tulah, sedih sebener nya dalem rumah keluar duduk, merenung nanges". (P3)

"Rasanya tuh sakit, ya kita kan di tinggal dari kecil, butuh lah bagaimana peran seorang ayah di kehidupan itu bagaiman, Sakit nian rasanya selama enam bulan rasanya, pedih "(P5)

"Sedih, sedih nian". (menangis) (P5)

"Iya sedih, sedih perasaannya sedih, ngerasa kayak ada yang hilang..selama 3 bulan"(P6)

Hasil penelitian terkait dengan kesedihan mendalam diidentifikasi sebagai suatu kehilangan yang sangat mendalam. Bagi seorang remaja baik putra maupun putri pasti memiliki perasaan kehilangan, tetapi dalam meluapkan dan mengekspresikan perasaannya berbeda, untuk remaja putra biasanya memiliki perasaan kehilangan yang cenderung sulit untuk diungkapkan, lebih pada menahan dan memendam perasaannya tersebut sedangkan untuk remaja putri cenderung lebih memiliki perasaan yang sensitif dan lebih peka, lebih menunjukkan kesedihan dan rasa kehilangannya.

Bersedih adalah reaksi terhadap kehilangan, yaitu respons emosional normal dan merupakan suatu proses untuk memecahkan masalah. Seorang individu harus diberikan kesempatan untuk menemukan koping yang efektif dalam melalui proses berduka, sehingga mampu menerima kenyataan kehilangan yang menyebabkan berduka dan merupakan bagian dari proses kehidupan (Yusuf, 2015).

Dukacita mengacu pada emosi yang subjektif dan afek yang merupakan respons normal terhadap pengalaman kehilangan.
Berduka juga mengacu pada proses mengalami dukacita. Mourn-ing, tampilan luar dukacita adalah suatu cara mengintegrasikan kehilangan dan dukacita kedalam hidup individu yang berduka (Varcolanis dan Marrone dalam Videbeck, 2001). Hasil penelitian ini senada dengan pendapat Papalia (2008) grief adalah respon emosional yang dialami pada fase awal berduka. Seseorang yang mengalami bereavement wajar apabila ia mengalami grief (berduka).

Menurut Schulz (dalam Yusuf 2014) fase awal seseorang menunjukkan reaksi syok, tidak yakin, tidak percaya, perasaan dingin, perasaan kebal, dan bingung. Perasaan tersebut berlangsung selama beberapa hari, kemudian individu kembali pada perasaan berduka berlebihan. Selanjutnya, individu merasakan konflik dan mengekspresikannya dengan menangis dan ketakutan. Fase ini akan berlangsung selama beberapa minggu.

Jika individu tetap berada di satu tahap dalam waktu yang sangat lama bahkan bertahun-tahun dan tidak mencapai tahap penerimaan, disitulah awal terjadinya gangguan jiwa. Suatu saat apabila terjadi kehilangan kembali, maka akan sulit bagi individu untuk mencapai tahap penerimaan dan kemungkinan akan menjadi sebuah proses yang disfungsional (Yusuf, 2015).

Hasil penelitian ini senada juga dengan pendapat Yusuf (2014) bahwa kehilangan memiliki dua fase yaitu fase akut yang berlangsung selama 4 sampai 8 minggu dan fase jangka panjang yang berlangsung selama satu sampai dua tahun atau lebih.

Hasil penelitian ini didukung oleh Suprihatin (2013) dengan kondiri Grief atau berduka atas kehilangan dari seseorang yang kita kenal terlebih kita cintai, akan berpengaruh terhadap kehidupan selanjutnya. Apa lagi jika kehilangan sosok orang tua, maka akan ada masa dimana kita meratapi kepergian mereka dan merasakan kesedian yang mendalam. Hal yang sama 
dengan penelitian Nurhidayati (2014) mengatakan bahwa ramaja mengungkapkan perasaan kehilangannya dengan menangis, merasa sedih, melakukan penolakan, dan menyesal.

Berdasarkan hasil penelitian dan teori di atas, peneliti beramsumsi bahwa kesedihan remaja terhadap kehilangan orang tua adalah kesedihan yang mendalam, karena kehilangan orang tua merupakan kehilangan seseorang yang kita kenal, dekat dan sangat kita cintai. Kehilangan orang tua bagi remaja merupakan suatu peristiwa yang tidak dapat dibandingkan dengan peristiwa-peristiwa lain, karena hal tersebut akan sangat berpengaruh terhadap kehidupan remaja selanjutnya, dengan kata lain kurang dapat menjalani kehidupan dengan baik. Bagi remaja dengan kehilangan orang tua yang tinggal di panti, kondisi panti asuhan dengan jumlah pengasuh yang tidak sebanding dengan remaja di panti asuhan dapat mejadi salah satu faktor resiko munculnya kesedihan. Remaja harus memiliki koping yang efektif dalam melalui proses bersedih, sehingga mampu menerima kenyataan kehilangan yang menyebabkan kematian orang tua yang dialaminya.

Berdasarkan teori di atas, peneliti berasumsi bahwa rentang waktu kesedihan yang dialami partisipan terhadap kehilangan orang tua berbeda-beda. Keadaan itu terjadi karena beberapa faktor diantara yaitu hubungan remaja dengan armahum, kepribadian, usia dan jenis kelamin serta proses kematian, guilt, anger, perasaan kehilangan. Seorang individu harus diberikan kesempatan untuk menemukan koping yang efektif dalam melalui proses berduka, sehingga mampu menerima kenyataan kehilangan yang menyebabkan berduka dan merupakan bagian dari proses kehidupan.

\section{Tema 2: Hilangnya seorang Figur orang tua}

Berdasarkan hasil penelitian didapatkan tema yang ketiga yaitu hilangnya seorang figur orang tua Pada kategori yang pertama adalah Bapak sebagai sosok pemberi role model, 2 dari 6 partisipan mengungkapkan bahwa bapak adalah sebagai sosok pemberi role model atau contoh yang dapat ditiru oleh anak-anaknya. Kategori yang ketiga yaitu ibu sebagai sosok pemberi nasihat dan semangat. 2 dari 6 partisipan mengungkapkan bahwa sosok ibu merupakan pemberi nasihat dan pemberi semangat baik untuk anaknya. Kategori yang keempat yaitu bapak sebagai figur pembimbing. Hanya partisipan 5 yang mengungkapkan bahwa figur orang tua itu sangat dibutuhkan. Hal tersebut tergambar pada ungkapan berikut:

"Sosok seorang bapak itu dulu nya taat pada agama, ngaji bisa pokok nya, sholat 5 waktu nggak pernah putus, kenapa nggak nurun sama aku, “.(P2)

"Yang pasti kehilangan sosok pemimpin dan orang tua” (P6)

" kehilangan sosok orang tua yang penuh perhatian dan peduli dengan aku....” (P3)

Ayah itu sholatnya rajin jadi dia itu ngasih contoh buat anak-anaknya sholat, sholat selalu ngajak jama'ah”. (P6)

"Ya kehilangan sosok orang tua" sering menyuruh sholat yang rajin ingin jadi anakknya yang sholeh ".(P1)

"Misalnya seperti ngasih arahan, nguatkan, neli harus kuat, ntar kalau misalnya ibu udah nggak ada, neli lah yang bisa nguatkan adek-adek, ”.(P4)

"Padahal aku butuh bimbingannya". (menangis) "Butuh lah bagaimana peran seorang ayah di kehidupan itu bagaimana, apalagi kita itu sudah remaja, pasti butuh bimbingan, dari ayah nggak dari ibu saja, “.(P5) 
Berdasarkan hasil penelitian yang dilakukan peneliti, didapatkan tema yang ketiga yaitu Kehilangan Sosok Pemimpin dengan 3 kategorinya adalah ibu bapak sebagai sosok pemberi role model, sebagai sosok pemberi nasehat dan penyemangat, dan bapak sebagai sosok pembimbing. Pada kategori yang pertama yaitu bapak sebagai sosok pemberi role model. Pada penelitian ini remaja mengungkapkan ahwa bapak adalah sebagai sosok pemberi role model atau contoh yang dapat ditiru oleh anakanaknya.

Hasil penelitian tersebut sejalan dengan penelitian yang dilakukan oleh Nurhidayati pada tahun 2014 yang berjudul Makna Kematian Orang Tua Bagi Remaja Menggunakan Studi Fenomenologi Pada Remaja Pasca Kematian Orang Tua, dari hasil wawancara keseluruhan terhadap sepuluh orang subjek, mengungkap kan bahwa makna kematian orang tua adalah kehilangan yang salah satunya adalah kehilangan figur yang dapat dijadikan sebagai panutan (role model).

Hasil penelitian tersebut sejalan dengan penelitian yang dilakukan oleh Nurhidayati pada yahun 2014 yang berjudul Makna Kematian Orang Tua Bagi Remaja Menggunakan Studi Fenomenologi Pada Remaja Pasca Kematian Orang Tua, dari hasil wawancara keseluruhan terhadap sepuluh orang subjek, mengungkap kan bahwa makna kematian orang tua adalah kehilangan yang salah satunya adalah kehilangan arah atau pembimbing.

Berdasarkan hasil penelitian dan teori di atas, peneliti beramsumsi bahwa kehilangan sosok pemimpin merupakan kehilangan sosok yang dapat dijadikan panutan, arahan, motivasi dan pembimbing bagi remaja. Remaja berada dalam masa peralihan dari kanak-kanak kemasa dewasa. Dalam masa peralihan, remaja sedang mencari identitasnya, dalam proses perkembangan yang serba sulit dan masa-masa membingungkan dirinya, remaja membutuhkan panutan, arahan, motivasi dan bimbingan serta bantuan dari orang yang dicintai dan dekat dengannya terutama orang tuanya. Karena orang tua adalah orang yang dekat dan mengerti akan anakanaknya, hangatnya sebuah keluarga akan membuat kedekatan yang terjalin antara anak dan orang tua, dan kedekatan itu akan membuat anak menjadi merasa aman dan nyaman, ketika seorang remaja dihadapkan pada suatu peristiwa yang tidak diinginkan dalam hidupnya pasti akan merasa berat untuk menerimanya, seperti peristiwa kehilangan yang memisahkan hubungan antara orang tua dan anak, peristiwa tersebut sulit untuk diterima oleh siapapun karena tidak ada satu orang pun yang akan benar-benar siap ketika harus kehilangan orang yang dicintainya.

\section{Tema 3 : Kasih Sayang yang berkurang}

Berdasarkan hasil penelitian didapatkan tema yang ketiga yaitu Kasih sayang yang berkurang. Pada kategori yang pertama yaitu kasih sayang seorang ibu, partisipan 1 mengungkapkan bahwa perhatian dan kasih sayang yang dulu didapatkan oleh partisipan tidak biasa ia dapatkan lagi setelah kehilangan ibu. Partisipan 1 terlihat sangat kehilangan ibu sebagai sosok pemberi perhatian dan kasih sayang, ia selalu menundukan kepala dan menyatakannya dengan suara berat seperti hendak menangis. Sedangkan partisipan 4 mengungkapkan bahwa ia masih terkenang kasih sayang seorang ibu yang pernah partisipan 4 rasakan. Kategori yang kedua yaitu Bapak sebagai sosok pemberi perhatian dan kasih sayang, 2 dari 6 partisipan mengungkapkan bahwa sangat kehilangan kasih sayang seorang bapak Hal tersebut terungkap pada pernyataan berikut:

"iyah..kalu Ibu tuh dengan saya perhatian kalau sekarang ya Bapak ya... perhatian cuman kurang tidak seperti Ibu perhatiannya". (menundukan kepala,suaranya berat) (P1)

" ya sejak ibu saya meninggal, kasih sayang orang tua berkurang dan 
perhatiannya tidak sepenuhnya yang dulu” (P2)

"Saya ingat itu pagi-pagi di bangunin ntar kesiangan, diantar ke sekolah di nasehatin belajar bener-bener jangan sampai dapat nilai jelek, pulang nya di jemput di siapin makan, suruh ganti baju dulu”. (P4)

"Ya tidak ada lagi kasih sayang dari orang tua sekarang tidak seperti yang dulu” (P3)

"Kehilangan itu pasti kehilangan sekali, soalnya kita masih kecil, masih butuh, sosok seorang ayah, dah masih kecil sudah ditinggalin yang sangat peduli dengan saya dan adik adik ". (P5)

"Ayah itu lucu jadi seneng anak-anaknya seneng gitu, ngak keras orangnya lembut, memberi perhatian kasih sayang”.(P6)

Berdasarkan hasil penelitian didapatkan tema yaitu kasih sayang yang berkurang dengan kategorinya adalah kasih sayang seorang ibu dan bapak sosok pemberi perhatian dan kasih sayang. Pada kategori yang pertama yaitu kasih sayang seorang ibu, remaja mengatakan bahwa mereka sangat kehilangan sosok ibu yang selalu memberikan kasih sayang dan perhatinnya serta remaja mengatakan bahwa mereka rindu akan kasih sayang seorang ibu yang dulu mereka dapatkan oleh partisipan dan sekarang tidak bisa ia dapatkan lagi setelah kehilangan ibu.

Hasil penelitian ini senada dengan pendapat. Diketahui juga bahwa remaja dapat bertahan dengan baik dari situasi yang menekan bila remaja mempunyai hubungan yang dekat dan penuh kasih sayang dengan orang tua terutama ibu. Dalam kondisi yatim atau yatim piatu, hubungan yang intim dengan orang tua tidak lagi diperoleh, dengan kondisi ini mereka harus tinggal di tempat selain rumah seperti yayasan atau panti asuhan karena tidak ada lagi orang yang merawatnya.

Hasil penelitian ini juga senada dengan pendapat Syam (2012) yang memandangnya dari perspektif psikologi agama. Syam menyatakan bahwa islam meletakan kaidah-kaidah yang menjaga hakikat kemanusiaan tersebut dalam hubungan antar individu. Salah satu kaidah tersebut adalah menyebarkan kasih sayang. Ini merupakan eksplorasi dari risalah islam sebagai ajaran yang utuh karena dia datang sebagai rahmat untuk seluruh alam.

Berdasarkan penelitian ini, kategori dari tema yaitu bapak sebagai figur pemberi perhatian dan kasih sayang. Remaja mengungkapkan bahwa mereka sangat kehilangan kasih sayang yang pernah didapatkan dari bapak sewaktu masih hidup. Remaja seakan rindu kepada sosok bapak yang perhatian dan penyayang.

Hasil penelitian ini sejalan Adina, (2013) sebagian besar remaja yang mengalami ketiadaan ayah pada usia 11 tahun sampai dengan 15 tahun (usia remaja) justru mengalami masalah emosi seperti merasa kesepian, merasa kesedihan, serta merasa kurang diperhatikan.

Pada penelitian yang dilakukan oleh Nurhidayati terdapat masalah yang mendasar pada remaja akibat kehilangan orang tua. Adapun masalah yang mendasar pada remaja adalah kurangnya kasih sayang yang seharusnya diperoleh remaja. Remaja yang tidak mendapatkan kasih sayang akan berusaha mendapatkan apa yang seharusnya dia peroleh. Kasih sayang adalah hal yang mutlak harus diperoleh setiap individu, kuhusnya remaja. Hal ini karena masa remaja adalah masa yang sangat rentan bagi setiap individu. Ketika remaja kehilangan figur yang seharusnya dapat memberikan kasih sayang, maka dia akan mencari figur yang mereka anggap dapat memberikan kasih sayang sebagaimana yang mereka inginkan.

Berdasarkan hasil penelitian dan teori di atas, peneliti beramsumsi bahwa kehilangan sosok pemberi kasih sayang merupakan keadaan diamana remaja tidak bisa lagi mendapatkan perhatian, perlindungan, rasa 
nyaman dan aman serta dukungan dari orang tua. Pada remaja yang tidak memiliki orang tua tekanan-tekanan yang dialami akan semakin banyak terkait dengan tidak adanya orang tua sebagai sumber kasih sayang, perlindungan dan dukungan. Ketiadaan orang tua merupakan kondisi yang sangat kompleks bagi remaja. Seperti halnya remaja yang tinggal di panti asuhan, mereka hanya mendapatkan lingkungan teman dan pengasuh menggantikan peran orang tua hanya memberikan perhatian juga membimbing secara terbatas.

Dengan sedikit bimbingan, remaja remaja harus mengatur hidup sendiri. Pengalamanpengalaman di panti akan berpengaruh terhadap konsep diri dan kepribadian remaja yang tinggal disana. Selain jumlah pengasuh yang tidak sebanding, panti asuhan sering dianggap sebagai lembaga yang hanya menampung dan memenuhi kebutuhan fisik saja sehingga kebutuhan lain seperti kebutuhan emosional tidak terpenuhi dengan baik. Remaja dengan kehilangan orang tua diasumsikan memiliki masalah psikologis yang lebih banyak jika dibandingkan dengan remaja pada umumnya yang tinggal dirumah, masih memiliki orang tua utuh dan keluarga yang dipenuhi kehangatan

\section{Tema 4: Tiada lagi tempat berbagi}

Dari hasil wawancara mendalam didapatkan tema yang kelima yaitu Kehilangan Tempat Berbagi dengan 2 kategorinya adalah Ibu sebagai tempat tempat memecahkan masalah dan Bapak sebagai tempat tempat bercerita dan berbagi. 2 dari 6 partisipan mengatakan bahwa ia sangat sedih kehilangan ibunya karena jika partisipan mendapatkan masalah hidupnya orang tua bisa partisipan 4 matanya merah seperti hendak menangisi. Kategori selanjutnya pada tema 4 yaitu kategori yang kedua adalah Bapak sebagai tempat tempat bercerita dan berbagi, berbeda dengan partisipan di atas, partisipan 2 dengan sedikit lantang mengatakan bahwa partisipan tidak ada teman mencurahkan isi hati. Hal itu terungkap seperti pada pernyataan berikut:

"Ya gimana yah.. sedih ngak bisa kumpul bareng, biasanya orang tua kalau ada masalah bisa memecahkan, kalau orang tua ngak ada ya..susah".(selalu menundukan kepala) (P1)

"Sering curhat sama ibu sekarang ngak bisa lagi” (P2)

"Susah tidak ada tempat berbagi masalah'. (matanya memerah) (P4)

"Aku nggak ada teman curhat aku ngadepin sendirian" (sedikit lantang) (P3)

“ sedih tidak ada lagi tempat berbagi masalah yang berat” (P5)

Berdasarkan hasil penelitian didapatkan tema yang kelima yaitu Kehilangan Kehilangan teman berbagi dengan kategorinya adalah Ibu sebagai teman memecahkan masalah dan Bapak sebagai teman bercerita dan berbagi. Pada kategori yang pertama yaitu Ibu sebagai teman memecahkan masalah, remaja mengungkapkan bahwa sosok seorang ibu sangat dibutuhkan untuk berbagi dan menyelesaikan masalah, remaja juga mengatakan bahwa kesulitan untuk menyelesaikan masalah kehidupannya jika tidak ada ibu.

Kategori selanjutnya pada tema 4 yaitu kategori yang kedua adalah Bapak sebagai teman mencurahkan isi hati, remaja mengatakan bahwa ia tidak menceritakan kehidupan keluarga kepada orang lain dan menghadapi masalahnya sendirian.

Hasil penelitian diatas senada dengan pendapat Sarwono (2016) yang menyatakan bahwa hubungan dengan orang tua yang pada masa remaja ini sangat dibutuhkan anak, jika terganggu dan dihadapkan dengan masalah atau harus diselesaikan bersama orang tua, menyebabkan remaja yang bersangkutan merasa seakan-akan tidak ada lagi jalan keluar. 
Hasil penelitian tersebut juga sejalan dengan penelitian yang dilakukan oleh Nurhidayati pada tahun 2014 berjudul Makna Kematian Orang Tua Bagi Remaja Menggunakan Studi Fenomenologi Pada Remaja Pasca Kematian Orang Tua, dari hasil wawancara keseluruhan terhadap sepuluh orang subjek, mengungkap kan bahwa makna kematian orang tua adalah kehilangan yang salah satunya adalah kehilangan teman berbagi.

Berdasarkan hasil penelitian dan teori di atas, peneliti beramsumsi bahwa kehilangan tempat berbagi merupakan kehilangan sosok seseorang yang dapat memahami, membantu dan menyelesaikan masalah yang dialami remaja. Remaja dengan kehilangan orang tua sangat membutuhkan teman tau tempat berbagi, seperti halnya remaja yang tinggal di panti asuhan, mereka hanya mendapatkan lingkungan teman sebaya yang mereka anggap sebagai tempat berbagi dan pengasuh atau pendidik walaupun itu terbatas itu sangat membantu. Karena remaja bisa merasakan dampak yang sangat besar akibat tidak mempunyai tempat atau teman untuk berbagi, mereka bisa menutup diri, tertekan dan mudah marah dan akibatnya remaja putus asa, depresi, dan akhirnya mengambil keputusan untuk bunuh diri saja.

Seperti halnya kehilangan sosok pemimpin dan kehilangan sosok pemberi kasih sayang, kehilangan teman berbagi juga merupakan bagian dari kehilangan orang tua karena kehilangan tersebut saling berhubungan. Remaja yang tidak mendapatkan sosok pemimpin yang dapat dijadikan panutan, tidak mendapatkan kasih sayang dan juga teman berbagi akan berusaha untuk mendapatkan apa yang harusnya mereka peroleh. Remaja akan mencari seseorang yang menurutnya bisa menjadi panutan, perhatian dan teman bercerita. Oleh karena itu peran keluarga, guru, teman dan pihak lain yang dekat dengan remaja harus mendukung untuk menyelesaikan tuga perkembangan remaja dengan baik.

\section{Tema 5 : Kehilangan Keutuhan Keluarga}

Partisipan memberikan penjelasan sesuai dengan pertanyaan yang diajukan oleh peneliti dalam proses wawancara ini. Dari hasil wawancara mendalam didapatkan tema yang keenam yaitu Kehilangan Keutuhan Keluarga dengan 3 kategorinya adalah perasaan sedih tidak bisa kumpul bersama dan keluarga tidah utuh lagi dan kondisi keluarga yang tidak lengkap. Pada kategori pertama yaitu perasaan sedih tidak bisa kumpul bersama, pada partisipan 1 dan 2 terlihat sedih dan merasa iri dengan teman-temannya bahwa teman-temanya sering dikunjungi orang tuanya sedangkan ia tidak serta selalu menundukan kepala. Hal itu terungkap seperti pada pernyataan berikut:

"Teringat kawan-kawan sering dilihat orang tua, bisa kumpul bareng sedangkan saya tidak bisa berkumpul dengan orang tua".(P1)

"Kadang sedih kalau berfikir (membayangkan) masih ada orang tua bisa kumpul bareng”. (selalu menundukan kepala) (P1)

"Sering sedih, ketika sedang sendiri bahkan sekarang masih terkenang , makanya saya itu nggak mau sendiri, karna pasti aku teringat sama orang tua kandung saya”.(menundukan kepala) (P2)

Kategori selanjutnya yaitu kategori yang kedua adalah keluarga yang tidak utuh lagi. 2 dari 6 partisipan mengatakan perasaan kekesalannya melihat orang lain mempunyai kedua orang tua yang masih utuh sedangkan partisipan 3 dan partisipan 4 tidak mempunyai orang tua yang lengkap karena telah meninggal salah satu orang tuanya. Hal tersebut terungkap pada pernyataan berikut:

"Baru sekarang sadar, ibaratnya nyesel lihat orang tua temen lengkap sedangkan saya tidak".(P3) 
"Di luar sana kawan-kawan masih mempunyai orang tua yang lengkap sedangkan neli nggak”.(P4)

Kategori yang ketiga adalah kondisi keluarga yang tidak lengkap. Seperti pada partisipan 6, ia menundukan kepala, menarik napas dan menyatakan bahwa kesedihannya melihat orang lain masih memiliki kesempatan bersama orang tua yang lengkap, berbeda dengan kondisi yang partisipan 6 rasakan sekarang. Hal tersebut terungkap pada pernyataan berikut:

"Mereka masih punya orang tua, bisa minta maaf sama orang tua,ya masih lengkaplah kedua orang tuanya, bisa buka puasa bareng-bareng, kalau kayak ginikan cuman ibu dan ibu ngak seseru ayah dulu bedalah waktu ayah ada atau ngak tetap beda”.(menarik napas, menundukan kepala) (P6)

Berdasarkan hasil penelitian didapatkan tema yang keenam yaitu Kondisi keluarga yang tidak lagi utuh, hal ini dikarenakan adanya orang tua yang tidak lagi lengkap bersama dengan remaja.

Hasil penelitian ini senada dengan pendapat Margaret (dalam Hurlock, 2007) melaporkan bahwa selain pemenuhan kebutuhan fisiologis, anak membutuhkan kasih sayang bagi perkembangan psikis yang sehat. Diketahui juga bahwa remaja dapat bertahan dengan baik dari situasi yang menekan bila remaja mempunyai hubungan yang dekat dan penuh kasih sayang dengan orang tua terutama ibu. Dalam kondisi yatim atau yatim piatu, hubungan yang intim dengan orang tua tidak lagi diperoleh, dengan kondisi ini mereka harus tinggal di tempat selain rumah seperti yayasan atau panti asuhan karena tidak ada lagi orang yang merawatnya.

Hasil penelitian ini sependapat dengan Glading (2002) yang mengungkapkan bahwa salah satu ciri keluarga yang disfungsional adalah ketidakseimbangan pola asuh seperti ibu yang terlalu melindungi atau sebaliknya.

Hasil penelitian di atas juga sejalan dengan penelitian yang dilakukan oleh Nurhidayati pada tahun 2014 yang berjudul Makna Kematian Orang Tua Bagi Remaja Menggunakan Studi Fenomenologi Pada Remaja Pasca Kematian Orang Tua, dari hasil wawancara keseluruhan terhadap sepuluh orang subjek, mengungkap kan bahwa makna kematian orang tua adalah kehilangan, salah satunya adalah kehilangan keutuhan keluarga.

Berdasarkan hasil penelitian dan teori di atas, peneliti beramsumsi bahwa kehilangan keutuhan keluarga merupakan kenyataan yang sulit diterima oleh remaja, karena jika remaja mengalami hal tersebut maka remaja akan merasa kurang mendapatkan perhatian, kasih sayang, kebersamaan dan perlindungan serta teman berbagi. Karena semuanya akan remaja dapatkan jika memiliki keluarga dan orang tua yang utuh dan pedulinya.

Keluarga merupakan lembaga sosial yang paling awal dikenal dan dekat dengan anak, maka peranannya dalam pendidikan dan proses pembentukan pribadi tampak dominan. Tumbuh dan berkembangnya aspek manusia baik fisik, psikis atau mental, sosial dan spiritual, yang akan menentukan bagi keberhasilan bagi kehidupannya, sangat ditentukan oleh lingkungan keluarga. Lingkungan keluarga yang kondusif sangat menentukan optimalisasi perkembangan pribadi, moral, kemampuan bersosialisasi, penyesuaian diri, kecerdasan, kreativitas juga peningkatan kapasitas diri menuju batasbatas kebaikan dan kesempurnaan dalam ukuran kemanusiaan. Pada dasarnya manusia itu mempunyai potensi yang positif untuk berkembang tetapi apakah potensi itu akan teraktualisasikan atau tidak sangat ditentukan oleh pendidikan dalam keluarga. 


\section{KESIMPULAN DAN SARAN}

Didapatkan lima tema yaitu: Kesedihan yang mendalam dalam rentang berbeda, hilangnya figure orang tua, kasih sayang yang berkurang, tiada lagi tempat berbagi dan kondisi keluarga yang tidak lagi utuh. Pengalaman kehilangan yang didapatkan dari remaja yang tinggal dipanti asuhan secara umum telah melewati fase kehilangan : penolakan, marah, depresi dan penerimaan. Pengalaman remaja panti asuhan tidak terjadi respon penolakan dalam periode yang lama dan fase penerimaan diikuti dengan unsur doa dan harapan.

Diharapkan dapat dilakukan perluasaan penelitian dalam kajian pengalaman kehilangan orang tua dengan dua jenis penelitian baik kuantitatif dalam mengidentifikasi pada setiap fase kehilangan ditambah dengan kualitatif.

\section{DAFTAR PUSTAKA}

Adina. (2013). Berduka pada Remaja dengan Kehilangan Orang Tua. Palembang. Jurnal Masker Medika STIKes Muhamamdiyah Palembang. 8(2). 39-49

Ahmad Yusuf. (2015). Buku Ajar Keperawatan Jiwa, Kehilangan. Jakarta: Salemba medika.

Afiyanti \& Rachnawati. (2014). Metodologi Penelitian Kualitatif dalam Riset Keperawatan Pendekatan Praktis. Edisi 1. Jakarta: Salemba Medika

Badan Pusat Statistika Sumatera Selatan, (2014). Jumlah Panti Asuhan Menurut Sumber Pembiayaan Dan Jumlah Anak Asuh Menurut Kabupaten/Kota Di Propinsi Sumatra Selatan.http://sumsel.bps.go.id/LinkT ableStatis/ view/ id /66 tanggal 22 Februari 2017.

Cahyasari, I (2008). Grief Pada Remaja Putra Karena Kedua Orang Tuanya Meninggal Universitas Gunadarma. Jakarta. Jurnal Psikologi Sosial; 14(1), 22-34.

Creswell, J. W. (2002). Educational Research: Planing, Conducting, and Evaluating Qualitatif Reserch. New Jersey: Mersill Printice Hall.

.(2007). Qualitative Inquiry and Reseach Desigh: Choosing Among Five Traditions. California: SAGE Publication, Inc. Thousand Oaks.

Departemen Agama RI. (2014). Al-Quran dan terjemaahnya (Al-Quran. An-nisa (4) ayat 78, At Taubah (9) ayat 51). Jakarta: PT.Syamil

Depkes RI. (2013). Riset Kesehatan Dasar (Riskesdas). Jakarta: Badan Penelitian dan Pengembangan Kesehatan. 
Dharma, K. K. (2011). Metodologi Penelitian Keperawatan, Panduan Melaksanakan dan Penerapan Hasil Penelitian. Desain penelitian. Jakarta: TIM

Gladding, S. T. (2002). Family Therapy; Hystory, Theory, and Practice (3rd Edition). London: Person Education, Inc.

Hasdianah Dkk. (2013). Buku Ajar Kesehatan Reproduksi. Yogyakarta: Nuha Medika.

Herdiansyah. (2010). Metodologi Penelitian Kualitatif. Jakarta: Salemba Humanika.

Himatun, Ayat, (2011). Himpunan Muslim Penyantun Anak Yatim Dan Anak Terlantar.http://himatunayat.org/read/ .tanggal 28 Februari 2017.

Hurlock, E. (2007). Psikologi Perkembangan. Jakarta: Erlangga.

Iyus, Yosep. 2011. Keperawatan Jiwa, Edisi 4. Jakarta: Refika Aditama.

Lumongga Lubis, Namora. (2013). Psikologi Kespro Wanita dan Perkembangan Reproduksinya Manusia. Jakarta: Lembaga Pengembangan Sarana Pengukuran dan Pendidikan Psikologi.

Maleong, Lexy J. (2008). Metode Penelitian Kualitatif. Bandung: PT Remaja Rosdakarya.

Nurhidayati, Lisya Chairani. (2014). "Studi Fenomenologi Makna Kematian Orang Tua Bagi Remaja Paska Kematian Orang Tua". Jurnal Kesehatan: 15(1), 27-37. Universitas Islam Negeri Sultan Syarif Kasim: Riau.

Papalia, D. (2008). Human Development. Jakarta: Kencana Prenada Grup.
Piaget, Jean dan Barbel Inhelder. (2010). Psikologi Anak Ter Miftahul Jannah Cetakan 1. Jakarta: Pustaka Pelajar

Poerwondari, E. K. (2009). Pendekatan Kualitatif untuk Penelitian Perilaku Publik, dan Ilmu Sosial Lainnya. Jakarta: Kencana.

$\begin{array}{lrr} & (2001) . & \text { Pendekatan } \\ \text { Kualitatif Dalam } & \text { Penenlitian } \\ \text { Psikologi. } \quad \text { Jakarta: } & \text { Lembaga } \\ \text { Pengembangan Sarana } & \text { Pengukuran } \\ \text { Dan Pendidikan Psikologi Iniversitas } \\ \text { Indonesia. }\end{array}$

Roumauli. (2009). Kesehatan Reproduksi. Yogyakarta: Nuha Medika.

Santrock, John. W. (2007). Remaja. Edisi 11. Jakarta: Erlangga

Sarlito W. Sarwono. (2016). Psikologi. Jakarta: Raja Grafindo Persada:

Spiaziale, H. J. S dan Carpenter, D. R. (2003). Qualititatif Research In Nursing. 3th Ed. Philadelphia: Lipincott Wiliams and Wilkins.

Strauss \& Corbin. (2003). Dasar-dasar penelitian kualitatif. Yogyakarta: Pustaka Pelajar.

Sugiyono, (2008). Metode Penelitian Kunatitatif Kualitatif dan $R \& D$. Bandung: Alfabeta.

Suprihatin , Adina. Fitria. (2013). Grief Pada Remaja Akibat Kematian Orang tua Secara Mendadak di Semarang. Jurnal Psikologi: 9.(1), 48-58. Universitas Negeri Semarang.

Syam, Nina Wangsih. (2012). Psikologi Sosial Sebagai AKar Ilmu Komunikasi. Banding: Simbiosa Rekatama Media.

Videbeck, Sheila L. (2001). Buku Ajar Keperawatan Jiwa (terjemaah dari Psychiatric Mental Health Nursing). 
Jurnal Aisyah: J urnal Ilmu Kesehatan, 3(1), J uni 2018, - 76

Suzanna

Jakarta: Penerbit Buku Kedokteran EGC.

Wita. (2015). Respon Berduka Pada Pasien Stroke di RSUP Haji Adam Malik

Medan. Skripsi. Tidak

Dipublikasikan. Universitas Sumatera Utara. 